\title{
PENGEMBANGAN MODEL PEMBELAJARAN PAI BERBASIS TIK YANG EFEKTIF PADA SMA NEGERI 4 KOTA KENDARI PROVINSI SULAWESI TENGGARA
}

\author{
The Development of Learning Model for Islamic Education Based on Valid and Effective \\ ICT at SMA 4 Kendari, Southeast Sulawesi
}

\author{
Zulkifli.M \\ Sekolah Tinggi Agama Islam Negeri Kendari \\ Jl.Sultan Qaimuddin No.17 Baruga Kendari \\ E-mail: zulkiflim58@ymail.com
}

Naskah diterima tanggal 30 Mei 2013. Naskah direvisi tanggal 3 Juli 2013. Naskah disetujui tanggal 23 Juli 2013

\begin{abstract}
Abstrak
Penelitian ini bertujuan untuk menemukan model pembelajaran Pendidikan Agama Islam (PAI) berbasis TIK yang valid dan efektif pada SMA Negeri 4 Kota Kendari. Penelitian ini termasuk jenis penelitian pengembangan atau research and development in education). Hasil yang diperoleh pada uji coba I adalah Model PAI TIK belum efektif, karena ketuntasan klasikal belum tercapai dan aktivitas siswa belum sesuai yang diharapkan, walaupun kemampuan guru PAI mengelola pembelajaran sudah dalam kategori tinggi dan respon siswa sudah dalam kategori positif. Hasil analisis ini digunakan untuk merevisi model dan perangkat pembelajaran sebelum dilakukan uji coba II. Hasil yang diperoleh pada uji coba II adalah Model PAI TIK sudah efektif, karena ketuntasan klasikal telah tercapai, aktivitas siswa sudah sesuai yang diharapkan, kemampuan guru mengelola pembelajaran sudah dalam kategori tinggi, dan respon siswa terhadap pembelajaran sudah dalam kategori positif. Hal yang menarik dalam penelitian ini adalah adanya kesungguhan dan keantusiasan siswa dalam belajar PAI dengan program moodle yang tertera dalam website SMA Negeri 4 Kota Kendari, dan seluruh siswa pada uji I dan II menyatakan senang mempelajari PAI berbasis TIK. Selain itu dengan model pembelajaran PAI berbasis TIK mereka menyatakan sangat setuju menerapkan model pembelajaran PAI berbasis TIK di sekolah. Selama uji coba berlangsung siswa dapat meningkatkan pengetahuan dan pemahaman serta keterampilan membaca Al quran, memahami hukum-hukum tajwid, menerjemahkan perkata, perpotongan ayat, dan perayat serta mampu menampilkan perilaku sesuai dengan bunyi ayat berlomba-lomba mencari kebajikan dan menyantuni kaum dhuafa.
\end{abstract}

Kata kunci: model pembelajaran PAI, Teknologi Informasi dan valid dan efektif.

\begin{abstract}
This research and development aims to find a learning model for Islamic Education based on valid and effective ICT at SMA Negeri 4 Kendari. The results obtained in the first trial was not effective because the classical completeness was not achieved yet and the students' activities were not as expected, however the ability of Islamic Education teachers in managing teaching and learning was in the high category as well as the students' responses were in the positive category. The analysis results were used to revise the model and the learning devices before the second trial was carried out. The results obtained in the second trial was already effective because the classical completeness was reached, the students' activities were as expected, the ability of Islamic Education teachers in managing teaching and learning was in the high category as well as the students' responses were in the positive category. The interesting points of the research were the students' seriousness and enthusiasm in learning Islamic Education with Moodle program listed in the website of SMA Negeri 4 Kendari, and the pleasure of the students to study Islamic Education based ICT.
\end{abstract}

Keywords: learning model of Islamic education, information and communication technology (ICT), valid and effective 


\section{PENDAHULUAN}

$\mathrm{M}$ unculnya era globalisasi, telah membuka wawasan dan kesadaran masyarakat dengan sejumlah harapan dan sekaligus kecemasan. Harapan-harapan ini muncul karena ada perbaikan kualitas hidup dan kehidupan di satu sisi sebagai akibat perkembangan dan penguasaan ilmu pengetahuan dan teknologi khususnya informasi dan komunikasi, dan disisi lain muncul juga kecemasan-kecemasan, hal ini disebabkan oleh adanya perubahan yang terlalu cepat menyebabkan kondisi masyarakat sulit untuk beradaptasi.

Perkembangan teknologi informasi beberapa tahun belakangan ini berkembang dengan pesat, sehingga dengan perkembangan tersebut telah mengubah paradigma masyarakat dalam mencari dan mendapatkan informasi, yang tidak lagi terbatas pada informasi media cetak dan media elektronik, tetapi juga sumber-sumber informasi lainnya seperti informasi dari dunia maya. Salah satu bidang yang mendapatkan dampak yang cukup berarti dalam perkembangan riset dan teknologi adalah bidang : (Asmani, 2011: 24).

Pendidikan adalah kodrat bagi manusia. Keberadaan pendidikan berlangsung dari satu generasikegenerasidisepanjangeksistensikehidupan manusia. Sasaran utama dalam pendidikan adalah membina kemampuan berkreativitas agar segala perubahan yang bermanfaat bagi kelangsungan dan perkembangan kehidupan dapat dicipta. Untuk itu, proses pendidikan difokuskan pada pembinaan tiga potensi kejiwaan yaitu rasa, cipta dan karsa yang pembinaannya diarahkan pada pencerdasan spiritual, intelektual dan moral (Suhartono, 2010: 27). Hal tersebut sejalan dengan amanat Undang-Undang RI Nomor 20 tahun 2003 bahwa pendidikan adalah usaha sadar dan terencana untuk mewujudkan suasana belajar dan proses pembelajaran agar peserta didik secara aktif mengembangkan potensi dirinya untuk memiliki kekuatan spiritual keagamaan, pengendalian diri, kepribadian, kecerdasan, akhlak mulia, serta keterampilan yang diperlukan dirinya, masyarakat, bangsa dan negara (Tim Redaksi Pustaka Yustisia, 2009: 98).

Berdasarkan hal tersebut maka pemerintah mengusahakan dan menyelenggarakan satu sistem pendidikan nasional yang meningkatkan keimanan dan ketakwaan kepada Tuhan Yang Maha Esa serta akhlak mulia dalam rangka mencerdaskan kehidupan bangsa. Pada umumnya pendidikan dipahami sebagai bidang studi dengan persoalan khas tentang pembimbingan, dan atau pembinaan. Adapun sasarannya adalah agar peserta didik menjadi lebih kompeten dalam menjalani kehidupan. Dalam kegiatan pendidikan dibatasi pada tiga aspek manusia yaitu: menurut susunan kodratnya sebagai individu berjiwa dan berbadan; menurut sifat kodratnya sebagai makhluk sosial, dan menurut kedudukan kodratnya sebagai makhluk Tuhan (Suhartono, 2010: 112)

Dari uraian di atas dapat dikemukakan bahwa pendidikan memperhatikan kesatuan aspek jasmani dan rohani, aspek diri (individualitas) dan aspek sosial, aspek kognitif, afektif, dan psikomotor, serta segi serba keterhubungan manusia dengan dirinya (konsentris), dengan lingkungan sosial dan alamnya (horizontal), dan dengan Tuhannya (vertikal).

Tujuan pendidikan memuat gambaran tentang nilai-nilai yang baik, luhur, pantas, benar, dan indah untuk kehidupan. Karena itu tujuan pendidikan memiliki dua fungsi yaitu memberikan arah kepada segenap kegiatan pendidikan dan merupakan sesuatu yang ingin dicapai oleh segenap kegiatan pendidikan. Salah satu bentuk pembelajaran yang diharapkan dapat mengembangkan potensi diri peserta didik dalam proses belajar mengajar adalah dengan menggunakan media berupa peralatan teknologi di bidang Teknologi Informasi dan Komunikasi (TIK). TIK termasuk di dalamnya internet, facebook, twitter, blog dan berbagai situs media sosial lainnya tumbuh sangat pesat di Indonesia dan menjadi sarana komunikasi yang sangat baik, menurut pengamat media sosial sampai 30 juta orang Indonesia menggunakannya dan hampir sebagian besar pengguna adalah pelajar (Yuswohady, 2011: 1). Pelajar merupakan generasi penerus bangsa, dimana pengaruh teknologi komunikasi sangat dominan di kehidupannya oleh karena itu pengarahan positif menggunakan teknologi komunikasi pada pelajar menjadi salah satu tugas bersama baik di dunia pendidikan maupun masyarakat. Tujuan dari sekolah dan kewajiban guru seperti yang disebutkan di atas diperuntukkan pada semua mata pelajaran yang 
ada di sekolah yang salah satunya di sini yaitu mata pelajaran Pendidikan Agama Islam (PAI).

Proses pembelajaran di SMA Negeri Kendari disampaikan oleh guru sesuai dengan profesinya atau keahliannya dalam mata pelajaran tertentu dan memanfaatkan teknologi informasi dan komunikasi sesuai dengan topik-topik yang disajikan. Pemanfaatan teknologi informasi dan komunikasi di dalam kelas cukup bervariasi penggunaannya, ada yang memanfaatkan teknologi informasi dan komunikasi di awal pelajaran, ada yang memanfaatkannya pada pertengahan proses pembelajaran, ada yang memanfaatkannya pada akhir proses pembelajaran, dan ada pula yang memanfaatkannya dari awal sampai akhir waktu pembelajaran, sehingga dengan keadaan demikian, maka penggunaan fasilitas teknologi informasi dan komunikasi di sekolah belum dimanfaatkan secara optimal (wawancara Safiilu, 6/5/2011). Khusus untuk pembelajaran Pendidikan Agama Islam di SMA Negeri 4 Kota Kendari masih ada guru Pendidikan Agama Islam yang belum memanfaatkan peralatan teknologi informasi dan komunikasi di sekolah, hal ini disebabkan karena belum terampil menggunakan alat-alat teknologi informasi dan komunikasi tersebut, tetapi sebahagian guru Pendidikan Agama Islam di SMA Negeri 4 Kota Kendari telah mampu dan terampil menggunakan TIK dalam proses belajar mengajar di kelas (wawancara Chairunnisa, 18/11/ 2011).

Menurut Drs. Ahmad Daaba, M.Pd (Wakil Kepala Sekolah Bidang Kurikulum SMA Negeri 4 Kendari) menyatakan bahwa pemanfaatan alat teknologi informasi dan komunikasi di SMA Negeri 4 Kendari tidak ada model yang baku, tetapi diserahkan kepada guru masing-masing mata pelajaran untuk memanfaatkan peralatan teknologi informasi dan komunikasi dalam pembelajaran. (Wawancara, 6/5/2011). Sedangkan keadaan pembelajaran/prestasi belajar siswa mata pelajaran Pendidikan Agama Islam (PAI) di SMA Negeri menurut Drs.Haddad Yahya (salah seorang guru mata pelajaran Pendidikan Agama Islam di SMA Negeri 4 Kendari) menyatakan bahwa prestasi belajar siswa mata pelajaran Pendidikan Agama Islam baru sekitar $40 \%$ siswa yang dianggap bagus/tinggi prestasi belajarnya, dan $60 \%$ siswa yang dianggap masih rendah prestasi belajarnya
(Wawancara, 28/5/2011). Hal ini dapat dilihat dari kriteria ketuntasan minimal (KKM) SMA Negeri 4 di Kota Kendari dalam setiap mata pelajaran, maka setiap siswa harus mendapatkan nilai minimal yang ditetapkan yakni $>72$ kalau belum tercapai, maka dilakukan remedial (Wawancara Kepala SMA Negeri 4 Kendari, 6-7/5/ 2011).

Berdasarkan uraian di atas, maka saya tertarik untuk melakukan penelitian yang berjudul "Pengembangan Model Pembelajaran Pendidikan Agama Islam (PAI) berbasis Teknologi Informasi dan Komunikasi (TIK) yang valid dan efektif di SMA Negeri 4 KotaKendari Provinsi Sulawesi Tenggara"

Berdasarkan uraian pada latar belakang di atas, maka permasalahannya adalah bagaimanakah mengembangkan Pendidikan Agama Islam (PAI) berbasis TIK yang valid dan efektif pada SMA Negeri 4 Kota Kendari? Sedangkan tujuan penelitian adalah dihasilkannya Pendidikan Agama Islam (PAI) berbasis TIK yang valid adn efektif pada SMA Negeri 4 Kota Kendari.

\section{Model Penelitian}

Jenis penelitian ini adalah research and development in education dan dilakukan di SMAN 4 Kendari kelas XI.IS2 program IPS dan kelas XI.IA1 Program IPA. Sedangkan subjek dalam penelitian ini adalah Guru PAI dan siswa kelas XI.IS2 dan kelas XI.IA1 SMAN 4 Kendari. Adapun objek dari penelitian ini adalah mata pelajaran Pendidikan Agama Islam (PAI) dengan menggunakan fasilitas TIK/Internet program moodle.

Adapun langkah-langkah penelitian mengacu pada tahapan Borg \& Gall (1981: 222) dapat dikemukakan sebagai berikut: Research and information collecting, Planning, Develop preliminary form of product, Preliminary field testing, Main product revision, Main field testing, Operational product revision, Operational field testing, Final product revision, serta Dissemination and distribution.

Langkah pertama adalah mengumpulkan data dan informasi dalam mendukung teori, observasi dalam kelas, dan menyiapkan laporan penelitian studi. Langkah kedua adalah perencanaan yakni mendefinisikan keterampilan, menentukan langkahlangkah kegiatan dan menguji skala kemungkinan 
pada tingkatan yang lebih kecil. Langkah ketiga adalah mengembangkan bentuk alat pendahuluan yakni menyiapkan petunjuk materi, buku panduan, dan menentukan evaluasi. Langkah keempat adalah menguji tempat/lapangan awal penelitian yakni produk diujikan pada satu sekolah, dengan menggunakan 6 sampai 12 subjek. Hasil wawancara, observasi, dan data kuesioner dikumpulkan dan dianalisis. Langkah kelima adalah merevisi produk yakni merevisi produk dengan menggunakan hasil uji lapangan awal penelitian. Langkah keenam adalah pengujian lapangan yakni pengujian ini dilakukan pada 1 sekolah dengan 25-30 subjek. Langkah ketujuh adalah merevisi operasional produk yakni merevisi operasional produk dilakukan melalui hasil uji lapangan inti. Langkah kedelapan adalah uji operasional lapangan yakni dilakukan pada 1030 sekolah termasuk 40-200 subjek mengumpulkan dan menganalisis hasil interview, observasi dan data kuesioner. Langkah kesembilan adalah revisi akhir produk yakni revisi akhir produk dilakukan berdasarkan hasil uji operasional lapangan. Langkah kesepuluh adalah penyebaran dan pendistribusian yakni laporkan hasil penelitian pada pertemuanpertemuan dan jurnal bekerjasama dengan penerbit yang bisa mendistribusikan hasil secara komersil. Mengawasi pendistribusian agar tetap terkontrol dan berkualitas.

Dalam penelitian ini akan berhenti pada tahap ketujuh, yaitu uji coba lapangan skala terbatas. Untuk tahap kedelapan, kesembilan dan kesepuluh tidak dilaksanakan karena pertimbangan adanya keterbatasan kemampuan pada peneliti.

\section{Desain Uji coba dan Produk Pengembangan}

Pelaksanaan uji coba merupakan bagian yang terpenting agar aplikasi yang dihasilkan layak untuk dipergunakan. Tahapan-tahapannya yaitu: validasi ahli materi, dan ahli media pembelajaran dan ahli teknologi informasi dan komunikasi (TIK); analisis konseptual; revisi pengembangan, berdasarkan penilaian para ahli pada tahap 1 berupa masukan, kritik atau saran ahli materi, ahli media, ahli teknologi informasi dan komunikasi (TIK) selanjutnya dilakukan perbaikan; uji coba terhadap teman sejawat (guru-guru PAI) dan pebelajar (satusatu dan kelompok kecil); analisis konseptual dan produk; revisi produk (tahap 2); uji coba lapangan terhadap pebelajar (siswa); penilaian pebelajar mengenai keefektifan produk.; analisis empirik (tahap 3); revisi kecil; dan rerwujudnya produk akhir pengembangan, berupa model konseptual, model prosedural dan model fisikal.

Pada tahap ini dihasilkan prototipe 1 (awal) sebagai realisasi hasil rancangan isi perangkat pembelajaran, sehingga dihasilkan pengembangan perangkat Pendidikan Agama Islam (PAI) berbasis TIK/e-learning yang .terdiri atas buku pedoman guru yang berisikan silabus, RPP, bahan ajar (e-materi, elks, dan slide presentation); buku pedoman evaluasi yang berisikan tes evaluasi yang berbasis TIK/e-learning (kuis online, tugas/ latihan online, penguasaan bahan ajar); dan buku penggunaan moodle yang berisikan buku petunjuk penggunaan moodle yang terdiri atas instalasi moodle, penggunaan moodle bagi guru dan siswa.

\section{Instrumen Pengembangan Model Pembelajaran PAI Berbasis TIK}

Secara umum tentang penyusunan instrumen yang digunakan dalam rangka pengembangan perangkat pembelajaran yaitu lembar validitas pengembangan model pembelajaran; lembar keberterimaan pengembangan model; lembar observasi keterlaksanaan pengembangan model pembelajaran; lembar observasi ke-mampuan guru mengelola pembelajaran; lembar obsevasi aktivitas siswa; angket respons siswa; dan instrumen penilaian kinerja guru.

\section{Kegiatan Validasi dan Analisis}

Kegiatan validasi isi dan validasi konstruk perangkat pembelajaran dilakukan dengan memberikan instrumen validasi pada para pakar dan praktisi. Para ahli yang bertindak sebagai validator adalah pakar Pendidikan Agama Islam dan yang berpengalaman dalam pengembangan model pembelajaran/ahli TIK, ahli TIK, ahli teknologi pembelajaran dan manajemen pendidikan, serta guru Pendidikan Agama Islam sebagai praktisi. Saran dari pakar dan praktisi tersebut digunakan sebagai landasan penyempurnaan pengembangan perangkat.

\section{Kegiatan uji coba Lapangan}

Uji coba dilakukan bertujuan untuk melihat keefektivan perangkat pembelajaran dalam 
pelaksanaan pembelajaran di kelas. Berdasarkan hasil ujicoba lapangan dan analisis data hasil uji coba dilakukan revisi. Sebelum ujicoba dilakukan, terlebih dahulu diberikan penjelasan pada guru mitra yang melaksanakan pembelajaran dan pengamat yang mengamati jalannya proses pembelajaran. Analisis validitas, analisis data keterlaksanaan perangkat pembelajaran PAI berbasis TIK/E-learning, analisis data kemampuan guru dalam pengelolaan pembelajaran PAI berbasis TIK/E-learning, analisis data aktifitas siswa terhadap pembelajaran PAI berbasis TIK/E-learning, analisis data respons siswa terhadap pembelajaran, analisis data penilaian kinerja guru (PKG) dalam proses pembelajaan, dan analisis hasil belajar.

Secara umum bahan ajar diketahui valid dengan melihat hasil validasi e-materi, slide presentation, LKS, tes penguasaan bahan ajar, Petunjuk penggunaan moodle, Silabus dan Rencana Pelakasanaan Pendidikan (RPP) yang digunakan. Keefektifan perangkat pembelajaran dapat diketahui dari indikator: penguasaan bahan ajar; lembar observasi aktifitas siswa; lembar observasi kemampuan guru mengelola kelas; lembar angket respons siswa. Dikatakan efektif jika memenuhi 3 dan 4 indikator, tetapi indikator 1 harus terpenuhi.

\section{PEMBAHASAN}

\section{Pembelajaran}

Pembelajaran (instruction) adalah suatu usaha untuk membuat peserta didik belajar atau suatu kegiatan untuk membelajarkan peserta didik. Dalam pengertian lain, pembelajaran adalah usahausaha yang terencana dalam memanipulasi sumbersumber belajar agar terjadi proses belajar dalam diri peserta didik (Sadiman, 1986: 7). Pembelajaran adalah upaya membelajarkan siswa untuk belajar. Kegiatan pembelajaran akan melibatkan siswa mempelajari sesuatu dengan cara efektif dan efisien (Muhaimin, 1996: 62). Pembelajaran adalah proses, cara, menjadikan orang atau makhluk hidup belajar (Barizi, 2009: 87). Dalam Undang-Undang RI Nomor 20 tahun 2003 tentang Sisdiknas Pasal 1 ayat 20 , pembelajaran adalah proses interaksi peserta didik dengan pendidik dan sumber belajar pada suatu lingkungan belajar (Depdiknas, 2003: 7). Oleh karena itu ada 5 (lima) jenis interaksi yang dapat berlangsung dalam proses belajar dan pembelajaran, yaitu: interaksi antara pendidik dengan peserta didik; interaksi antar sesama peserta didik; interaksi antar sesama peserta didik dengan narasumber; interaksi peserta didik bersama pendidik dengan sumber belajar yang sengaja dikembangkan; dan interaksi peserta didik bersama pendidik dengan lingkungan sosial dan alam (Miarso, 2008: 3).

Kegiatan belajar hanya bisa berhasil jika peserta didik belajar secara aktif mengalami sendiri proses belajar. Kegiatan pembelajaran ini akan menjadi bermakna bagi peserta didik jika dilakukan dalam lingkungan yang nyaman dan memberikan rasa aman bagi peserta didik. Belajar akan efektif jika dilakukan dalam suasana menyenangkan (Dryden, 2002: 22).

Ada 3 (tiga) teori dalam pembelajaran, yaitu behaviorisme, kognitivisme, dan konstruktivisme. Mayer (2001) mengusulkan istilah lain dari ketiga teori pembelajaran tersebut di atas agar mudah dipahami yaitu: a) pembelajaran sebagai penguasaan respons (behaviorisme); b) pembelajaran sebagai penguasaan pengetahuan (kognitivisme); dan c) pembelajaran sebagai konstruksi pengetahuan (konstruktivisme) (Shambaugh \& Magliaro, 2006:5).

Seorang guru, harus memiliki sejumlah kiat dalam melakukan pembelajaran. Kiat yang dimiliki, bukan saja untuk mencapai tujuan pembelajaran, tetapi lebih jauh dari itu adalah dalam rangka menumbuhkan minat belajar siswa. Seorang guru yang berkompetensi, cerdas dan professional memiliki seperangkat kiat khusus dalam kelas. Dengan itu pula dia akan menjadi guru yang dirindukan kehadirannya di kelas (Mukhtar dan Iskandar, 2010: 8).

Ada enam langkah yang bisa ditempuh guru pada waktu ia mengajar dengan mempergunakan media. Langkah-langkah itu ialah: merumuskan tujuan pengajaran dengan memanfaatkan media; persiapan guru. Pada fase ini guru memilih dan menetapkan media mana yang akan dimanfaatkan guna mencapai tujuan; persiapan kelas. Pada fase ini siswa atau kelas harus mempunyai persiapan, sebelum mereka menerima pelajaran dengan menggunakan media; langkah pe-nyajian pelajaran dan pemanfaatan media; langkah kegiatan belajar siswa. Pada fase ini siswa belajar dengan memanfaatkan media pengajaran; langkah evaluasi pengajaran. Pada langkah ini kegiatan belajar di 
evaluasi, sampai sejauh mana tujuan pengajaran tercapai, yang sekaligus dapat dinilai sejauhmana pengaruh media sebagai alat bantu dapat menunjang keberhasilan proses belajar siswa. Hasil evaluasi dapat dijadikan dasar atau bahan bagi proses belajar berikutnya (Djamarah, 2010: 136).

Dari uraian di atas, maka dapat dikemukakan bahwa pembelajaran adalah merupakan suatu kumpulan prinsip-prinsip yang terintegrasi dan memberikan preskripsi untuk mengatur situasi agar peserta didik mudah mencapai tujuan pembelajaran, sehingga seorang guru harus memperlihatkan kemampuannya dalam mendesain materi pelajaran sehingga dapat membangkitkan minat dan menumbuhkan bakat siswa dalam proses belajar mengajar dengan menggunakan : atau strategi dan media pembelajaran yang sesuai berupa peralatan fasilitas teknologi informasi dan komunikasi yang memadai serta melakukan evaluasi hasil belajar dengan melihat aspek kognitif, afektif dan psikomotorik sesuai dengan tujuan yang diharapkan.

\section{Pengembangan Model Pembelajaran}

Pengembangan adalah proses menerjemahkan spesifikasi desain ke dalam suatu wujud fisik tertentu (Seels \& Rickey, 1994: 23). Secara utuh, kegiatan pembelajaran memerlukan desain agar arah dan kegiatan pembelajaran dapat mencapai tujuan yang diharapkan. Proses desain dimulai dari identifikasi masalah atau identifikasi kebutuhan pembelajaran dan diakhiri dengan identifikasi bahan dan strategi pembelajaran, sedangkan proses pengembangan dimulai dari memilih atau mengembangkan bahan pembelajaran dan menuangkannya dalam strategi pembelajaran yang telah didesain, kemudian diakhiri dengan mengevaluasi strategi berikut bahan pembelajaran tersebut, untuk meningkatkan efektivitas dan efisiensinya (Dick, Carey, \& Carey, 2005: 213). Bila dilihat dari beberapa teori di atas terlihat bahwa pengembangan pembelajaran adalah suatu proses yang meliputi desain, produksi, dan evaluasi.

\section{Model Pembelajaran}

Robbins (1996: 25) mendefinisikan "A model is an abstraction of reality, a simplified representation of some real word phenomenon". Maksudnya, model merupakan representasi dari beberapa fenomena yang ada di dunia nyata. Pandangan serupa juga diungkapkan oleh Miarso (2008: 12), yang mendefinisikan model sebagai berikut: "Model adalah representasi suatu proses dalam bentuk grafis dan/atau naratif, dengan menunjukkan unsur-unsur utama serta strukturnya. Dalam hal ini dimungkinkan penafsiran model naratif ke dalam bentuk grafis, atau sebaliknya".

Pentingnya model dalam pembelajaran dijelaskan Gustafson dan Branch (2002:1), bahwa model membantu kita mengkonseptualkan representasi dari kenyataan, menyederhanakan realitas karena kerapkali kondisi nyata terlalu kompleks untuk dipotret.

Penilaian kualitas model pembelajaran merujuk pada kriteria kualitas kurikulum yang dikemukakan oleh Nieveen (1999: 127-128) yakni validitas dan keefektifan. Untuk menilai validitas model dapat digunakan dua kriteria, yaitu: model yang dikembangkan didasarkan pada rasional teoritik yang kuat; model memiliki konsistensi secara internal. Sedangkan kriteria keefektifan model ada dua yakni model yang dikembangkan efektif menurut penilaian dan pengalaman ahli atau praktisi dan model yang dikembangkan dapat memberikan hasil sesuai dengan harapan.

Kerangka model pembelajaran PAI berbasis TIK ini terdiri atas syntax, sistem social, prinsip reaksi, system pendukung, dampak instruksional dan dampak pengiring. Pertama sintaks, merupakan fase-fase atau langkah-langkah kegiatan dalam suatu model yang diwujudkan dalam rangkaian kegiatan pembelajaran. Sintaks ini dirancang dengan langkah-langkah yang dapat dilakukan guru, kegiatan pembelajaran yang logis, mencirikan adanya kemampuan yang bersifat kognitif, afektif dan psikomotorik, serta memuat dengan jelas peran guru dan siswa.

Kedua sistem sosial, merupakan kondisi atau situasi atau aturan yang berlaku dalam suatu model pembelajaran. Polahubungan antaraguru dan siswa menunjukkan pola interaksi dalam pembelajaran dapat berbentuk satu arah, dua arah, atau multi arah. Dalam komunikasi interaksi dua arah, guru dan siswa dapat berperan sama, yakni masingmasing sebagai pemberi dan penerima aksi. Hal ini dapat lebih menghidupkan suasana kegiatan 
belajar siswa. Dalam komunikasi transaksi (multi arah), proses pembelajaran lebih memungkinkan siswa berkembang secara optimal dalam kegiatan belajarnya. Diskusi dan simulasi merupakan metode yang sesuai dengan jenis komunikasi ini. Syah (2000) mengemukakan perlunya komunikasi multi arah dalam situasi pembelajaran dengan harapan untuk menggalakkan student active learning. Dalam konteks ini proses pembelajaran selayaknya dipandang sebagai kegiatan sebuah system yang memproses siswa sebagai "input" agar mereka terdorong secara intrinsic untuk melakukan aktivitas belajar khususnya di dalam kelas. Hasil yang diharapkan adalah output yang tercermin pada perubahan positif dalam diri siswa, baik dalam dimensi ranah cipta, rasa maupun karsanya.

Ketiga prinsip reaksi, merupakan pola kegiatan yang menggambarkan respons guru yang wajar terhadap siswa, baik secara individu dan kelompok, maupun secara keseluruhan. Prinsip reaksi juga berkaitan dengan teknik yang diterapkan guru dalam memberi reaksi terhadap perilaku-perilaku siswa dalam kegiatan pembelajaran, seperti bertanya, menjawab, menanggapi, mengkritik dan sebagainya. Joyce, Weil \& Shower (2009) secara garis besar mengemukakan bahwa prinsip reaksi merupakan pedoman bagi guru dalam menghargai dan merespons stimulus berupa perilaku-perilaku siswa dalam proses pembelajaran. Beberapa perilakuguruyang diharapkan dalam pembelajaran PAI adalah menciptakan suasana yang kondusif untuk pembelajaran dan membangkitkan motivasi siswa untuk belajar, misalnya dengan menyiapkan siswa untuk belajar (menenangkan siswa) dan menyampaikan kompetensi dasar dan indikator pencapaian hasil belajar; menyediakan dan mengelola sumber-sumber belajar yang relevan yang dapat mendukung kelancaran proses pembelajaran PAI seperti buku siswa, LKS, dan slide presentation; mendemonstrasikan atau mengarahkan siswa untuk mengkonstruksi pengetahuan melalui internet program moodle; Meminta siswa untuk merefleksikan hasil pembelajaran melalui internet program moodle dan mengaplikasikannya dalam kehidupan sehari-hari; Menghargai segala aktivitas siswa yang mendukung proses : (penguatan positif) dan mengarahkan aktivitas siswa yang menghambat proses pembelajaran (penguatan negative).

Keempat sistem pendukung suatu model pembelajaran adalah hal-hal yang dapat mendukung tercapainya tujuan pembelajaran dengan menerapkan model itu (Suparno, 2000). Hal-hal yang dimaksud berupa sarana, bahan, perangkat, dan alat bantu atau media. Untuk model PAI TIK ini dibutuhkan sarana pendukung seperti silabus, RPP, Buku Materi PAI, Slide Presentation, LKS, lembar evaluasi, dan internet program moodle.

Kelima dampak instruksional dan dampak pengiring. Joyce, Weil \&Shower (2009) menegaskan bahwa penerapan suatu model pembelajaran diarahkan untuk menopang pencapaian secara optimal sasaran atau tujuan pembelajaran yang telah ditetapkan. Pada prinsipnya pengguna model harus berupaya mensinergikan semua komponen model itu dalam rangka mencapai tujuan pembelajaran. Tujuan pembelajaran terbagi atas tujuan utama yang bersifat segera/ mendesak untuk dicapai (instructional effect) dan tujuan pengikut/pengiring yaitu tujuan yang tidak segera dapat dicapai atau hasilnya tidak segera dapat dipetik setelah pembelajaran berlangsung, tetapi diharapkan dalam waktu yang relative lama (nurturant effect). Dampak instruksional untuk model PAI TIK ini adalah tercapainya penguasaan bahan ajar: Islam khususnya aspek Al quran yang berkenaan dengan pencapaian kompetensi dasar dan indicator hasil belajar PAI yang direncanakan dalam RPP. Sedangkan dampak pengiring dalam model PAI TIK ini adalah adanya kemandirian siswa dalam belajar PAI, keaktifan belajar dan sikap positif terhadap mata pelajaran Pendidkan Agama Islam.

\section{Pembelajaran Pendidikan Agama di SMA}

Pendidikan Agama Islam di sekolah dapat dipahami sebagai suatu program pendidikan yang menanamkan nilai-nilai Islam melalui proses pembelajaran, baik di kelas maupun di luar kelas yang dikemas dalam bentuk mata pelajaran dan diberi nama Pendidikan Agama Islam disingkat PAI (Syahidin, 2009: 1). Pendidikan agama Islam diharapkan menghasilkan manusia yang selalu 
berupaya menyempurnakan iman, takwa, dan akhlak, serta aktif membangun peradaban dan keharmonisan kehidupan, khususnya dalam memajukan peradaban bangsa yang bermartabat. Manusia seperti itu diharapkan tangguh dalam menghadapi tantangan, hambatan, dan perubahan yang muncul dalam pergaulan masyarakat baik dalam lingkup lokal, nasional, regional maupun global. Misi utama PAI adalah membina kepribadian siswa secara utuh dengan harapan kelak mereka akan menjadi ilmuwan yang beriman dan bertakwa kepada Allah swt., mampu mengabdikan ilmunya untuk kesejahteraan umat manusia (Syahidin, 2009:1).

\section{Tujuan Pendidikan Agama Islam di SMA/MA}

Pendidikan Agama Islam di SMA/MA bertujuan untuk menumbuhkembangkan akidah melalui pemberian, pemupukan, dan pengembangan pengetahuan, penghayatan, pengamalan, pembiasaan, serta pengalaman peserta didik tentang Agama Islam sehingga menjadi manusia muslim yang terus berkembang keimanan dan ketakwaannya kepada Allah swt; mewujudkan manusia Indonesia yang taat beragama dan berakhlak mulia yaitu manusia yang berpengetahuan, rajin beribadah, cerdas, produktif, jujur, adil, etis, berdisiplin, bertoleransi (tasamuh), menjaga keharmonisan secara personal dan sosial serta mengembangkan budaya agama dalam komunitas sekolah. Menurut Abdul Fattah Jalal (1990: 5) bahwa tujuan pendidikan Islam adalah menjadikan manusia sebagai abdi atau hamba Allah swt.

\section{Perangkat Pembelajaran}

Perangkat pembelajaran adalah sekumpulan sumber belajar yang memungkinkan guru dan siswa melakukan kegiatan pembelajaran. Ada beberapa komponen perangkat pembelajaran dalam penelitian ini, yakni silabus, Rencana Pelaksanaan Pembelajaran (RPP), materi PAI (pegangan guru dan siswa), LKS, slide presentation dan alat evaluasi.

Bahan ajar interaktif melalui internet yang digunakan dalam penelitian ini di sajikan dalam program moodle yang telah dirancang untuk membantu guru dalam mengajar. Menurut Munir (2009: 180) moodle merupakan software belajar dinamis dengan menggunakan model berorientasi objek atau merupakan paket lingkungan pendidikan berbasis web yang dinamis. Adapun kelebihan moodle, antara lain: penggunaannya tepat untuk kelas online; hasil belajar relative sama baiknya dengan belajar secara langsung tatap muka dengan pengajar; pengajar mempunyai hak istimewa, yaitu dapat mengubah (memodifikasi) materi pembelajaran; teknologi yang digunakan bersifat sederhana, sehingga mudah, relative murah, dan efisien; programnya mudah diinstall; programnnya cukup satu database yang diperlukannya; pelajaran dilengkapi dengan tampilan penjelasan; keamanan yang terjamin dengan baik; serta disediakan paket untuk berbagai bahasa.

\section{Identifikasi Kebutuhan Awal}

Dalam penelitian ini diawali dengan melakukan survey/observasi awal dan melakukan pertemuan dengan guru bidang studi Pendidikan Agama Islam pada SMA Negeri 4 Kota Kendari. Dalam pertemuan tersebut peneliti melakukan wawancara singkat dengan guru PAI untuk mengetahui sejauhmana proses pembelajaran mata pelajaran Pendidikan Agama Islam dan pendekatan pembelajaran atau model pembelajaran yang digunakan. Dari hasil wawancara tersebut peneliti memperoleh informasi bahwa pelajaran PAI khususnya aspek Al-Qur'an masih sulit dipahami siswa kelas XI-1 (IPA-IPS) dan guru PAI kelas XI-1 belum menerapkan model pembelajaran berbasis TIK khususnya program moodle. Pada kesempatan yang sama peneliti juga membicarakan langkah-langkah metode pembelajaran dengan menggunakan internet program moodle, dan selanjutnya peneliti memberikan informasi tentang jenis penelitian yang akan dilakukan sekaligus merencanakan waktu pelaksanaan penelitian dan kelas yang akan dijadikan sebagai subjek penelitian.

Peneliti juga melakukan survei/need assessment terhadap sekolah, guru dan siswa SMA Negeri 4 Kota Kendari, dengan mengajukan beberapa pertanyaan. Dari keseluruhan jawaban yang dikemukakan dalam angket tersebut, baik yang berasal dari siswa maupun yang berasal dari guru dapat disimpulkan bahwa perlu adanya model pengembangan pembelajaran PAI berbasis TIK pada SMA Negeri 4 Kota Kendari. 


\section{Perencanaan Pengembangan}

Perencanaan yakni

keterampilan, menentukan

kegiatan, dan menguji skala kemungkinan pada tingkatan yang lebih kecil. Keterampilan yang diinginkan dalam penelitian pengembangan ini adalah agar siswa dan guru terampil dalam menggunakan peralatan TIK ke dalam program moodle yang dapat diakses melalui internet, dalam pelaksanaan proses belajar mengajar. Dalam hal penggunaan alat-alat TIK yang dituangkan dalam program moodle, maka disusunlah buku petunjuk penggunaan moodle baik guru, maupun siswa. Selain itu langkah selanjutnya adalah menyiapkan perangkat pembelajaran Pendidikan Agama Islam di kelas XI sesuai dengan kurikulum yang berlaku. Menetapkan guru mitra dan pengamat, serta tim validator ahli pendidikan.

\section{Mendesain Model}

Desain model dalam penelitian ini adalah pengembangan model pembelajaran PAI berbasis TIK pada SMA Negeri 4 Kota Kendari. Desain model konseptual merupakan desain yang berkaitan dengan teori-teori yang melandasai dari proses pengembangan model pembelajaran PAI berbasis TIK, yang melahirkan buku model. Kemudian desain model procedural yakni menggunakan langkah-langkah penelitian dan pengembangan dari Borg \& Gall, sedangkan perangkat pembelajaran PAI menggunakan langkah-langkah dari Dick and Carey. Selanjunya desain model fisikal yakni terwujudnya model PAI berbasis TIK dalam bentuk buku dan compack disc (CD).

Desain model dalam bentuk buku model yang didalamnya diuraikan hal-hal yang berkaitan dengan teori-teori dasar dan pendukung model pembelajaran PAI berbasis TIK, kemudian Sintaks pembelajaran PAI, sistem sosial, prinsip reaksi (perilaku guru), sistem pendukung, dampak instruksional dan pengiring, pelaksanaan pembelajaran, lingkungan belajar dan tugas-tugas pengelolaan, dan evaluasi.

Desain perangkat pembelajaran PAI dapat dikemukakan sebagai berikut: silabus PAI Kelas XI-1; materi PAI (Buku Pegangan Guru dan Buku Siswa); rencana pelaksanaan pembelajaran (RPP); lembar kegiatan siswa (LKS); slide Presentation dari materi PAI; petunjuk penggunaan moodle (guru dan siswa); serta penilaian/evaluasi hasil belajar.

\section{Validasi dan uji coba produk. Uji Validasi}

Sebelum melakukan uji coba lapangan, maka terlebih dahulu dilakukan validasi terhadap produk yang telah dibuat. Validasi dilakukan dengan cara menunjuk ahli di bidang pendidikan. Adapun Uji validasi yang dimaksud adalah sebagai berikut: a) Validasi buku model; b) Validasi Silabus PAI; c) Validasi materi PAI(Buku pegangan guru dan Siswa); d) Rencana Pelaksanaan Pendidikan (RPP); e) Lembar Kerja siswa (LKS); f) Slide Presentation; g) Media TIK; h) Desain pembelajaran; i) Penilaian/ evaluasi hasil belajar.

\section{Hasil Validasi Ahli untuk Perangkat Pembelajaran}

Aspek-aspek yang diperhatikan dalam memvalidasi buku model PAI adalah teori-teori pendukung, sintaks, sistem sosial, prinsip reaksi (perilaku guru), sistem pendukung, dampak instruksional dan pengiring, pelaksanaan pembelajaran, lingkungan belajar dan tugas-tugas pengelolaan, dan evaluasi hasil belajar. Hasil validasi buku model PAI mencapai rata-rata 3,84 yang berarti sangat valid. Selanjutnya validasi silabus mencapai rata-rata 3,82 yang berarti sangat valid, RPP 3,79 sangat valid, materi PAI untuk guru dan siswa 3,62 sangat valid, slide presentation 3,80 sangat valid, LKS 3,77 sangat valid, petunjuk penggunaan moodle (guru dan siswa) 3,36 valid, evaluasi hasil belajar 3,81 sangat valid.

Hasil pada uji coba I pada kelas XI-IS-2 dan uji coba II kelas XI IA-1, aktivitas siswa mengikuti pembelajaran PAI berbasis TIK dari keseluruhan siswa kelas IPS IS-2 sebanyak 33 orang, terdapat 29 orang atau $87,88 \%$ aktif mengikuti pembelajaran PAI di kelas, sedangkan 4 orang atau 12,12\% kurang aktif karena melakukan kegiatan yang tidak berkaitan langsung dengan pembelajaran PAI. Pada uji coba II siswa kelas IPA IA-1 sebanyak 36 orang, terdapat 31 orang atau 86,11 \% aktif mengikuti pembelajaran PAI di kelas, sedangkan 5 orang atau 13,89 \% kurang aktif karena melakukan kegiatan yang tidak berkaitan langsung dengan pembelajaran PAI.

Adapun respon siswa kelas XI IS-2 terhadap model pembelajaran berbasis TIK terdapat $85,69 \%$ 
menyatakan senang, sangat baik dan positif, dengan alasan bahwa pembelajaran PAI berbasis TIK ini dapat mempercepat proses akses materi, eksploratif, cepat, tepat, efektif, efisien, menarik, menyenangkan dan membangun silaturrahmi melalui diskusi online. Sedang kelas XI IA-1 pada uji coba II dinyatakan bahwa terdapat 90,75\% menyatakan senang, sangat dan positif terhadap model pembelajaran PAI berbasis TIK. Sedangkan pengelolaan pembelajaran oleh guru PAI dinilai terlaksana seluruhnya yang mencapai rata-rata 3,04 untuk kelas XI IS-2 dan 3,21 untuk kelas XI IA-1.

\section{Nilai Hasil Belajar Uji Coba I untuk Kelas XI-IS-2}

Hasil belajar pretest siswa kelas XI-IS-2 yang berjumlah 33 orang (muslim-muslimah) sebelum uji coba I dimulai menunjukkan bahwa yang mendapatkan kategori sangat rendah sebanyak 87,88 \% yang berarti bahwa lebih dari $50 \%$ siswa tidak mencapai standar ketuntasan belajar yang diharapkan. Sedangkan hasil belajar post test atau setelah dilakukan 6 kali pertemuan, maka hasilnya adalah terdapat $45,45 \%$ mendapatkan nilai sangat rendah, rendah sampai tinggi mencapai 54,55\% yang berarti bahwa lebih $50 \%$ siswa telah mencapai standar ketuntasan belajar yang diharapkan.

Nilai Hasil Belajar Uji Coba II pada Kelas XI-IA-1

Hasil belajar pretest siswa kelas XI-IA-1 yang berjumlah 36 orang (muslim-muslimah) sebelum uji coba I dimulai menunjukkan bahwa yang mendapatkan kategori sangat rendah sebanyak 19 orang atau $52,78 \%, 14$ orang atau $38,89 \%$ mendapatkan nilai rendah, sebanyak 3 orang atau $8,33 \%$ mendapatkan nilai sedang. Tidak satupun yang mendapat nilai tinggi dan sangat tinggi. Jadi lebih dari $50 \%$ siswa tidak mencapai standar kompetensi belajar yang diharapkan.. Sedangkan hasil belajar post test atau setelah dilakukan 6 kali pertemuan, maka hasilnya adalah terdapat 1 orang atau 2,78 \% mendapatkan nilai sangat rendah, kemudian 1 orang atau 2,78\% yang mendapat nilai rendah, terdapat 22 orang atau $61,11 \%$ yang mendapat nilai sedang, dan yang mendapat nilai tinggi sebanyak 12 orang atau $33,33 \%$, dan tidak ada satupun siswa yang mendapatkan nilai sangat tinggi. Jadi terdapat $73,44 \%$ berada pada kategori sedang dan tinggi, yang berarti bahwa lebih $50 \%$ siswa telah mengalami peningkatan hasil belajar yang diharapkan dengan kata lain telah mencapai standar ketuntasan belajar yang diharapkan.

\section{PENUTUP}

Proses pengembangan model pembelajaran PAI berbasis TIK ini melalui beberapa langkah pengembangan yaitu: langkah pertama melakukan identifikasi awal atau penelitian pendahuluan; langkah kedua melakukan perencanaan produk; langkah ketiga mengembangkan produk atau menyiapkan petunjuk materi, buku panduan dan menentukan evaluasi serta validasi produk; langkah keempat uji coba I produk; langkah kelima merevisi hasil uji coba I; langkah keenam melakukan uji coba II; langkah ketujuh melakukan revisi akhir hasil uji coba II. Proses fase 1 sampai 3 menghasilkan prototype-1 model PAI TIK (model hipotetik), sedangkan proses pengembangan pada fase keempat sampai ketujuh adalah melakukan validasi dan uji coba untuk menghasilkn model PAI TIK yang valid dan efektif. Untuk keperluan uji coba model PAI TIK dilakukan pembelajaran dengan mengikuti sintaks model PAI TIK yang meliputi: penyampaian tujuan pembelajaran dan mempersiapkan siswa terarah jelas dalam program moodle; mendemonstrasikan pengetahuan atau keterampilan (siswa membaca dan mempelajari dengan seksama materi yang telah disiapkan dalam program moodle; membimbing siswa jika mengalami kesulitan dalam memahami materi, baik melalui bimbingan langsung maupun melalui forum diskusi yang telah disiapkan dalam program moodle; mengecek pemahaman dan memberikan umpan balik (siswa mengerjakan kuis dan uji kompetensi yang ada pada e-materi masingmasing KD; serta memberikan kesempatan untuk pelatihan lanjutan dan penerapan.

Hasil-hasil yang dicapai melalui proses uji coba model adalah uji coba I dengan hasil yang dicapai yaitu model PAI TIK belum efektif, karena ketuntasan klasikal belum tercapai dan aktivitas siswa belum sesuai yang diharapkan, walaupun kemampuan guru mengelola pembelajaran dalam kategori tinggi dan respon siswa dalam kategori positif. Uji coba II, hasil yang dicapai yaitu model PAI TIK sudah efektif, karena ketuntasan klasikal telah tercapai, aktivitas sudah sesuai yang diharapkan, kemampuan guru mengelola 
pembelajaran dalam kategori tinggi, dan respon siswa terhadap pembelajaran dalam kategori positif. Maka diperoleh model pembelajaran PAI berbasis TIK yang valid dan efektif. Model PAI TIK tersebut memiliki sintaks pengajaran langsung dengan fasefasenya, dan memiliki komponen lain yang meliputi teori pendukung, interaksi sosial/sistem sosial, prinsip reaksi, dan system pendukung perangkat pembelajaran.

\section{UCAPAN TERIMA KASIH}

Terima kasih dan penghargaan yang setinggitingginya kepada informan yang telah meluangkan waktu terutama kepada kepala sekolah SMA 4 Kota Kendari beserta guru-guru SMA 4 Kota Kendari, terima kasih pula penulis sampaikan kepada ketua STAIN Kendari yang telah memfasilitasi penulis melakukan penelitian di SMA 4 Kota Kendari, ucapan yang sama kepada rekan-rekan penulis yang telah memberikan sumbangsi saran dan kritik dalam penyempurnaan artikel ini. Khusus untuk pengelolah jurnal Al-Qalam terima kasih atas diterbitkannya artikel ini.

\section{DAFTAR PUSTAKA}

Asmani, J.M. 2011. Tips Efektif Pemanfaatan Teknologi Informasi dan Komunikasi Dalam Dunia Pendidikan. Yogyakarta: DIVA press.

Barizi,A. \& Idris.M. 2009. Menjadi Guru Unggul Bagaimana Menciptakan Pembelajaran yang Produktif dan Profesional. Yogyakarta: ArRuzz Media.

Borg, Walter R. 1981. Applying Educational Research A Practical Guide for Teachers. New York \& London: Longman Inc.

Depdiknas. 2003. Undang-Undang Republik Indonesia Nomor 20 Tahun 2003 tentang Sistem Pendidikan Nasional. Jakarta: Biro Hukum dan Organisasi Depdiknas.

Dick, Walter., Carey, Lou. \& Carey, James O. 2005. The Systematic Design Of Instruction ( $6^{\text {th }} \mathrm{ed}$.). Boston, Pearson.

Djamarah, SB \& Aswan Zain. 2010. Strategi Belajar Mengajar.Jakarta: Rineka Cipta.

Dryden, Gordon \& Vos, Jeannette. 2002. Revolusi Cara Belajar The Learning Revolution. Bandung: Kaifa.
Gustapson, K.L. dan Branch. 2002. Survei of Instructional Development Models. New York: Eric Clearinghouse on Information and Techhnology Syracuse University.

Jalal, Abdul Fattah. 1998. Azas-Azas Pendidikan Islam. Bandung: Diponegoro.

Joyce, Bruce, dkk. 2009. Models of Teaching ModelModel Pengajaran. Yogyakarta: Pustaka Pelajar.

Mayer E.Richart. 2001.Multimedia Learning. New York: Cambridge University Press.

Miarso, Yusufhadi. 2008. Penerapan Teknologi Informasi dan Komunikais Dalam Pendidikan di Era Globalisasi. Jakarta: Makalah Seminar Nasional The Power of ICT in Education, PPs UNJ, 15 April 2008.

Muhaimin, dkk. 1996. Strategi Belajar Mengajar. Surabaya: Citra Media.

Mukhtar \& Iskandar. 2010. Desain Pembelajaran Berbasis Teknologi Informasi dan Komunikasi (Sebuah Orientasi Baru). Jakarta: Gaung Persada Press

Munir. 2009. Pembelajaran Jarak Jauh Berbasis TIK. Bandung: Alfabeta.

Nieveen, Nienke. 1999. Prototyping to Reach Product Quality. In Jan Van den Akker, R.M. Branch, K. Gustafson, N. Nieveen, \& Tj. Plomp. Design Approaches and Tools in Education and Training. Dordrecht, The Netherlands: Kluwer Academic Publisher.

Robbins, Stephen P. 1996. Organizational Behavior: Concepts, Controversies, Applications $(7 \mathrm{~m}$ Ed.). Prentice-Hall International, Inc.

Sadiman, Arief dkk. 1986. Media Pendidikan, Pengertian, Pengembangan, dan Pemanfatannya. Jakarta: Rajawali.

Seels, Barbara B. \& Rickey, Rita C. 1994. Instructional Technology: The Definition and Domain of the Field. Washington DC, Association for Educational Communication and Technology. Shambaugh, Neal \& Susan G.Magliaro. 2006. Instructional Design. United States of America: Lybrary of Congress Cataloging in Publication Data.

Suhartono, Suparlan. 2010. Pengantar Ilmu Pendidikan. Makassar: Badan Penerbit UNM.

Suparno, Herawati. 2000. Aplikasi Pendekatan Konstruktivistik Dalam Pembelajaran IPA- 
Biologi Sekolah Menengah dan Pengaruhnya Terhadap Minat dan Motivasi Belajar Mahasiswa di Perguruan Tinggi. Makalah Seminar Nasional Makassar: Lembaga Penelitian UNM Makassar.

Syah, Muhibbin. 2000. Psikologi Pendidikan Dengan Pendekatan Baru. Bandung: PT.Remaja Rosdakarya.
Syahidin. 2009. Menelusuri Metode Pendidikan Dalam Al-Qur'an. Bandung: Alfabeta

Tim Redaksi Pustaka Yustisia. 2009. Kompilasi Perundangan Bidang Pendidikan. Yogyakarta: Pustaka Yustisia.

Yuswohady. 2011. http://networked blog.com/ cygRx. 